\title{
EFFECTS OF CADMIUM, AN ENVIRONMENTAL AND OCCUPATIONAL POLLUTANT, ON LIPID PEROXIDATION IN RAT PANCREATIC TISSUE
}

\author{
UDC 546.68:577.115
}

\author{
Jasmina Jovanović Mirković ${ }^{1}$, Gordana Kocić², Ružica Nikolić3 \\ ${ }^{1}$ College of Nursing, Ćuprija, Serbia \\ ${ }^{2}$ Faculty of Medicine, University of Niš, Niš, Serbia \\ ${ }^{3}$ Department of Chemistry, Faculty of Sciences and Mathematics, University of Niš, Niš, \\ Serbia
}

\begin{abstract}
Technological development, industrialization and economic development have improved living standards, but also increased toxic metal emissions in the living and working environment. The aim of this study is the monitoring of lipid peroxidation in case of acute intoxication by heavy metal cadmium and the protective role of $\alpha$-lipoic acid. In this study, we used healthy albino Wistar female rats, two or three months old. Based on the results obtained in this study, we note that cadmium-induced intoxication increases the level of malondialdehyde (MDA) in the pancreatic tissue homogenate. MDA is a direct indication of lipid peroxidation. Alpha-lipoic acid suggests reduction and correction of the toxic effect of cadmium after its exposure.
\end{abstract}

Key words: Heavy metals, cadmium, $\alpha$-lipoic acid, malondialdehyde, lipid peroxidation

\section{INTRODUCTION}

Heavy metals occur naturally in soil in certain concentrations. Heavy metals which are not of geochemical but rather of anthropogenic origin can often be found in the surface layers of soil. They reached soil as a result of different human activities (industry, fossil fuel combustion, application of agrochemicals, atmospheric deposition, etc.). This leads to permanent contamination of soil and groundwater [1].

Volcanic activity is one of the reasons for the occasional increase in the concentration of cadmium $(\mathrm{Cd})$ in the environment, primarily in the air. Constant sources of cadmium contamination are related to its application in industry. Cadmium is introduced into the body in the form of dust vapours and particles as oxide, chloride, fluoride, sulphide,

Received January 17, 2018 / Accepted June 29, 2018

Corresponding author: Jasmina Jovanović Mirković

College of Nursing, Lole Ribara 1/2,35230 Ćuprija, Serbia

E-mail: ninamjovanovic@gmail.com 
carbonate and acetate [2]. Absorption is mainly performed by the respiratory tract, and to a smaller extent by the gastrointestinal tract, while the transcutaneous path is insignificant [3]. The kidneys and liver together contain from 50 to $60 \%$ of the body's accumulation of cadmium [4]. Highly toxic effect of cadmium is the result of its interactions with the necessary micro and macro bioelements, especially with iron, calcium, copper and zinc [5]. The presence of cadmium in nutrition reduces iron absorption while increasing zinc absorption in the gastrointestinal tract [6]. In the absence of these elements, the cadmium absorption level is elevated.

Cadmium poisoning can be acute and chronic. Acute poisoning occurs by inhalation of cadmium salt vapours or particles (oxide, chloride, sulfide, sulphate, carbonate and acetate). Symptoms of acute exposure to cadmium are nausea, vomiting, loss of smell, taste and appetite, abdominal pain. Chronic occupational poisoning may occur after long-lasting exposure to cadmium by inhalation or oral route. Unlike acute, chronic intoxication can lead to the development of certain diseases, for example, chronic obstructive pulmonary disease, lung emphysema, kidney disease (nephrotoxicity) and bone disease (arthritis, osteoporosis) [7], prostatic carcinoma, anaemia, alopecia, frequent migraines, growth disorder and cardiovascular diseases $[8,9]$. There is no medical chelation method that is completely effective for treating cadmium toxicity.

Lipid peroxidation is oxidative damage that reaches cell membranes, lipoproteins and other molecules containing lipids in the conditions of oxidative stress [10,11]. This is the most frequent consequence of free radical activity. The lipid peroxidation process represents only one consequence of oxidative stress present in the cell at an inadequate balance of the formation and elimination of free radicals. Lipid peroxidation is one of the best-studied processes of cell damage in the conditions of oxidative stress [12]. The once initiated reaction of peroxidation continues autocatalytically, has a progressive flow, and as the final outcome has structural-functional changes in the substrate [13]. The end product of lipid peroxidation is MDA. It shows pronounced cytotoxic effects. The reaction between MDA and proteins, RNA, DNA or phospholipids may lead to the modification of these substrates and damage to cell membranes and intracellular molecules [14]. MDA is a reactive potential mutagen and carcinogen.

Alpha-lipoic acid ( $\alpha$-LA), 6,8-dithioctanoic acid, is a cyclic disulphide, and via the carboxyl group, it is linked to the protein part of the enzyme as an amide. $\alpha$-LA was first isolated in 1951 by Reed et al. [15]. It participates in the oxidative decarboxylation process of $\alpha$-keto acids. It exhibits great activity in very small quantities. The effect of $\alpha$-lipoic acid is reflected in the intensification of ATP synthesis [16], it participates in the assimilation of lactic acid, activates the enzymes of the tricarboxylic acid cycle, stimulates the growth of lactic-acid fermentation bacteria by replacing acetate (acetate transfer factor), stimulates the synthesis of CoA (fatty acid utilization), prevents liver damage by various toxicants, and normalizes the level of aldolase and transferase.

\section{THE AIM OF THE RESEARCH}

The aim of this study is to observe lipid peroxidation in the conditions of acute cadmium heavy metal intoxication by measuring the value of malondialdehyde (secondary lipid peroxidation product). This study also considers the protective role of $\alpha$-lipoic acid in the conditions with and without intoxication by this toxic metal. 


\section{MATERIALS AND METHODS}

Experimental white (albino) female Wistar rats, 2 months old, were grown in laboratory conditions, in which food and water were available ad libitum, in the vivarium of the Faculty of Medicine in Niš, Serbia. The animals were divided into 4 groups of five animals. Group I (control group) was on a normal diet and living regime. Group II was intoxicated with cadmium (II) chloride $(\mathrm{CdCl} 2)$. Cadmium intoxication was performed in 5 days and in two s.c. injections of $0.9 \mathrm{mg}$ of cadmium (II) chloride in physiological solution per animal [17]. Along with cadmium (II) chloride, Group III received the corresponding supplement $\alpha$-lipoic acid. Group IV received supplemental $\alpha$-lipoic acid with a normal diet. The addition of $\alpha$-lipoic acid was dosed by i.p. injection in a total dose of $2.4 \mathrm{mg}$ in physiological solution per animal (7 doses in 21 days) [18]. The experimental work fully complied with the Code of Ethics for Scientific Research of the Faculty of Medicine in Niš.

From $10 \%$ of the pancreatic tissue homogenates prepared in the appropriate medium, the following research was carried out: the analysis of determining malondialdehyde concentrations $[19,20]$ and protein concentrations in the homogenate of the examined organ. Biochemical reagents were Sigma-Aldrich of the spectroscopic grade.

\subsection{Determination of the concentration of lipid peroxidation products (TBARS) in the homogenate of the pancreatic tissue}

The lipid peroxidation intensity in the pancreatic tissue presented as the TBA concentration of the reacting substances in the homogenate was determined by the spectrophotometric method of Andreeva et al. (1988), based on the MDA reaction with thiobarbituric acid (TBA), at high temperature and in acidic environment, leading to the creation of a chromogen (MDA-TBA2) [21].

\section{STATISTICAL ANALYSIS}

All measurement results are shown as the mean \pm SD. Student's t-test for independent samples was applied for statistical data processing (Microsoft Office Excel). The statistically significant results are shown as $\mathrm{p}<0.05$. The results of these analyses are presented in graphs.

\section{RESULTS AND DISCUSSION}

Lipid peroxidation is an indicator of oxidative stress in cells and tissues. In the lipid peroxidation process, unsaturated fatty acids of cell membranes are degraded. This leads to the release of the same and reduction of the activity of cell membrane-bound enzymes (glucose-6-phosphatase and cytochrome P-450) [22]. Lipid peroxidation products are easily detected by certain spectrophotometric methods and are used to measure the level of oxidative stress [21]. The concentration of malondialdehyde is most commonly determined. Increased MDA concentrations indicate the presence of oxidative stress due to the disturbance of balance between the prooxidative and the antioxidant system.

Malondialdehyde (MDA) is the end product of the lipid peroxidation process. This compound is a reactive aldehyde that causes oxidative stress in cells and is the biomarker of the oxidative stress level in the body or individual organs. The degree of lipid peroxidation is assessed by measuring the level of MDA in different tissues. 
A model system for testing the effects of cadmium intoxication in the working and living environment is the exposure of rats to cadmium at a dose of $0.9 \mathrm{mg} / \mathrm{kg}$ which is lower than the exposure to this metal in highly contaminated environments [23].

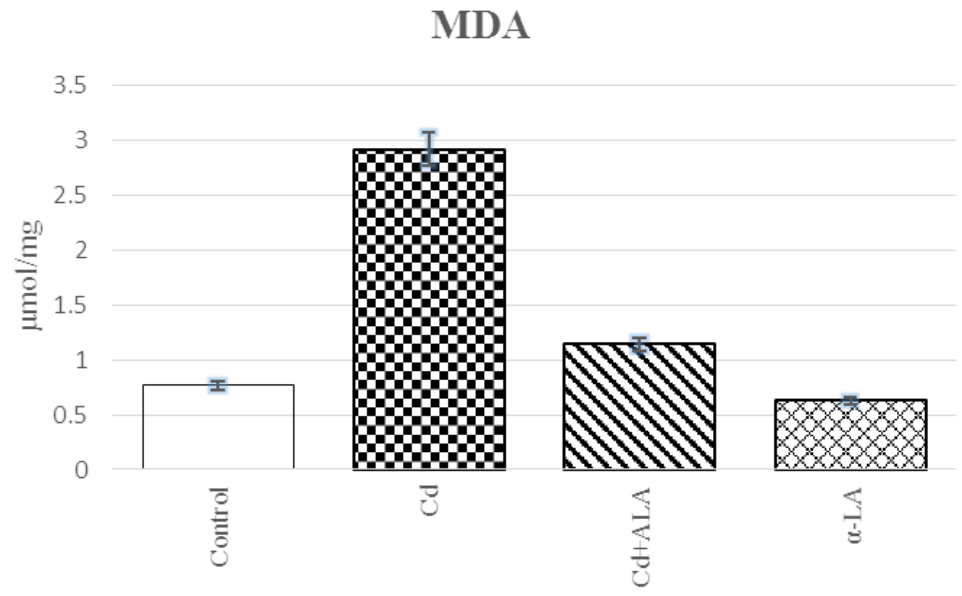

Fig. 1 Values of MDA ( $\mu \mathrm{moV} \mathrm{mg})$ concentration in pancreatic tissue homogenate of albino Wistar rats

From the results in Fig. 1 it can be noted that under conditions of acute cadmium intoxication, the level of MDA increases in the pancreatic tissue homogenate (from $0.77 \pm$ 0.20 to $2.92 \pm 0.48$ ) in relation to the control group of animals. The results of this study show that after cadmium poisoning, the level of TBARS, an indicator of lipid peroxidation, significantly increases. The direct consequence of cadmium exposure in vivo is probably the exhaustion of physiological antioxidants such as reduced glutathione and proteins containing -SH groups as one of the mechanisms of cadmium toxicity. In the group of experimental animals in which, along with cadmium, $\alpha$-lipoic acid was applied as a supplement, the concentration of TBARS is significantly reduced (from $2.92 \pm 0.48$ to 1.14 \pm 0.17 in the pancreas) compared to the cadmium-intoxicated group (Figure 1). This antioxidant reduces damage caused by exposure to radiation, and according to some sources it can be also used in treating diabetes [24], as well as preventing complications of this (cardiomyopathy, neuropathy, and retinopathy) and other diseases.

According to the literature data, the reduced form of lipoic acid has the ability to regenerate oxidized glutathione, vitamin $\mathrm{C}$ and vitamin $\mathrm{E}$, which is existentially significant for maintaining cell redox status $[25,26]$. The application of $\alpha$-lipoic acid probably reduces the formation of free radicals thus preventing tissue damage by free radicals.

This experiment demonstrated the useful role of $\alpha$-LA supplement with the antioxidant character in the prevention and reduction of unwanted effects of acute cadmium intoxication. Antioxidant indirectly protects the cell from oxidative stress by acting as a potential scavenger of free radicals. This leads to the break of the lipid peroxidation chain reaction. 


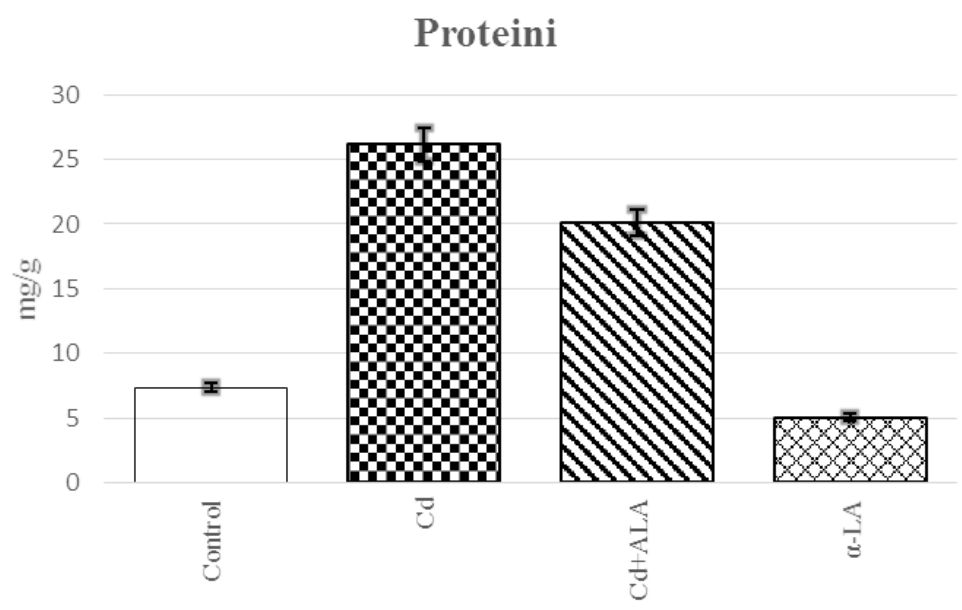

Fig. 2 Values of protein concentration (mgg)

in pancreatic tissue homogenate of albino Wistar rats

The results of the protein content in pancreas following acute cadmium intoxication and administering of $\alpha$-LA supplement are shown in Figure 2. The protein level can be a significant biochemical parameter that can be applied to the diagnosis and prognosis of many diseases. According to the results obtained in this work, in the conditions of acute $\mathrm{Cd}$ intoxication, the protein content significantly changes in the examined organ. Its level is somewhat normalized in the presence of supplements ( $\alpha$-lipoic acid) compared to the group of experimental animals that received cadmium. Reduction of protein concentration in the examined organ homogenate (pancreas) due to acute heavy metal $(\mathrm{Cd})$ intoxication indicates a negative nitrogen balance, while elevated values in the examined organs with the application of supplement ( $\alpha$-lipoic acid) indicate a positive nitrogen balance thus speaking of cell metabolic activity.

\section{CONCLUSION}

The results of the measurement of values of malondialdehyde (MDA), a secondary product of lipid peroxidation, are used as an indicator for the observation of cell membrane damage in oxidative stress. Cadmium increases the level of lipid peroxidation. Based on the results of this research, it can be concluded that the level of lipid peroxides is significantly reduced in case of adding $\alpha$-lipoic acid supplement one day after intoxicating rats with cadmium. The lipid peroxidation process underlies many pathological conditions and diseases.

Acknowledgement: This work was supported by the Ministry of Education, Science and Technological Development of the Republic of Serbia under the Project No. TR31060. 


\section{REFERENCES}

1. Alina, M., Azrina, A., Mohd Yunus, A.S., Mohd Zakiuddin, S., Mohd Izuan Effendi, H., Muhammad Rizal, R., (2012), Heavy metals (mercury, arsenic, cadmium, plumbum) in selected marine fish and shellfish along the Straits of Malacca. Int Food Res J., 19(1), 135-140.

2. Han, J.X., Shang, Q., Du, Y., (2009), Effect of environmental cadmium pollution on human health. Health, 1(3), 159-166.

3. Lauwerys, R., (1979), Cadmium in man, The chemistry, biochemistry and biology of cadmium. North Holland Biomed. Press, Elseiver, 433-453.

4. Nikolić, R., Jovanović, J., Kocić, G., Cvetković, T., Stojanović, S., Anđelković, T., Krstić, N., (2011), Monitoring the effects of exposure to lead and cadmium in working and living environment through standard biochemical blood parameters and liver endonucleases activity. Hemijska industrija, 65(4), 403-409.

5. Brzoska, M., Moniuszko-Jakoniuk, J., (1997), Calcium deficiency as on of the risk factors of osteoporosis. Postepy Hig. Med. Dosw. 51(1), 55-74.

6. Friberg, L., Nordberg, GF. Vouk, VB., (1986), In: Handbook on the Toxicology of Metals, Elsevier, Amsterdam, New York, Oxford, 521-531.

7. Ogoshi, K., Yukuo, N. Moriyama, T., (1992), Decrease in bone strength of cadmium-treated young and old rats. Arch. Toxicol., 66(5), 315-320.

8. Bernard A., (2008), Cadmium \& its adverse effects on human health. Indian J Med Res., 128(4), 557-564.

9. Chakraborty, S., Dutta, A.R., Sural, S., Gupta, D., Sen, S., (2013), Ailing bones and failing kidneys: a case of chronic cadmium toxicity. Ann Clin Biochem., 50(5), 492-495.

10. Halliwell, B.I. and Gutteridge, J.M.C., (1985), Lipid peroxidation a radical chain reaction, Free radicals an biology and medicine. Oxford, Clarendom Press, 189-193.

11. Slater, T.F., (1984), Free-radical mechanisms in tissue injury. Biochem. J., 222(1), 1-15.

12. Farber, J.L., Kyle, M..E., Coleman, J.B., (1990), Mechanisms of cell injury by activated oxygen species. Lab. Invest., 62(6), 670-679.

13. Đorđević, V., Pavlović, D., Kocić, G., (2000), Biochemistry of free radicals, Niš, Sirius Print, (1).

14. Sreejayan, N., Von Ritter, C., (1999), Lipid peroxidation in bile: the role of hydrophobic bile acids and the effect on biliary epithelial cell function. Patophysiology, 5(4), 225-232.

15. Reed, LJ., DeBusk, BG., Gunsalus, IC., Hornberger, C.S., (1951), Crystalline $\square$-lipoic acid: a catalytic agent associated with pyruvate dehydrogenase. Science, 114, 93-94.

16. Harris, RA., Joshi, M., Jeoung, NH., Obayashi, M., (2005), Overview of the molecular and biochemical basis of branched-chain amino acid catabolism. J. Nutr., 135(6), 1527S-1530S.

17. Deepti Gaurav, Shabad Preet, Dua K.K. Chronic cadmium toxicity in rats: Treatment with combined administration of vitamins, amino acids, antioxidants and essential metals, Journal of Food and Drug Analysis, 2010; 18(6), 464-470.

18. Fuke H., Iwanami K., Watanabe, Kumada S. Acute, subacute and chronic toxicities of thioctic acid in rats. Niphon Yakurigaku Zasshi, 1972; 68(3), 265-275.

19. Kocić, G., Pavlović, D., Pavlović, R., Nikolić, G., Cvetković, T., Stojanović, I., Jevtović, T., Kocić, R., Sokolović, D., (2004), Sodium nitroprusside and peroxynitrite effect on hepatic DNases: An in vitro and in vivo study. Comp. Hepatol., 3(6), 1-9.

20. Kocić, G., Vlahović, P., Pavlović, D., Kocić, R., Jevtović, T., Cvetković, T., Stojanović, I., (1998), The possible importance of the cation-binding site for the oxidative modification of liver 5 -nucleotidase. Arch. Physiol. Biochem., 106(2), 91-99.

21. Andreeva, L., Kozhemiakin, L., Kishkun, A., (1988), Modification of the method of determining lipid peroxidation in a test using thiobarbituric acid. Laboratornoe delo, 11, 41-43.

22. Yoshikawa, T., Toyokuni, S., Yamamoto, Y., Naito, Y., (2000), In: Free Radicals in Chemistry Biology and Medicine, OICA International, Saint Lucia, London.

23. Shaikh Z.A., Vu T.T., Zaman K. Oxidative stress as a mechanism of chronic cadmium-induced hepatotoxicity and renal toxicity and protection by antioxidants. Toxicology and Applied Pharmacology, 1999; 154(3), 256-263.

24. Jacob, S., Streeper, R.S., Fogt, D.L., Hokama, J.Y., Tritschler, H.J., Dietze, G.J., Henriksen, E.J., (1996), The antioxidant alpha-lipoic acid enhances insulin-stimulated glucose metabolisam in insulin-resistant rat skeletal muscle. Diabetes, 45(8), 1024-1029.

25. Stoyanovsky, D.A., Tyurina, Y.Y., Tyurin, V.A., Anand. D., Mandavia, D.N., Gius, D., Ivanova, J., Pitt, B., Billiar, T.R., Kagan, V.E., (2005), Thioredoxin and lipoic acid catalyze the denitrosation of low molecular weight and protein S-nitrosothiols. J. Am. Chem. Soc., 127(45), 15815-15823.

26. Da Ros, R., Assaloni, R., Ceriello, A., (2005), Molecular targets of diabetic vascular complications and potential new drugs. Curr Drug Targets, 6(4), 503-509. 


\section{EFEKAT KADMIJUMA, EKOLOŠKOG I ZDRAVSTVENOG POLUTANTA, NA PROCES LIPIDNE PEROKSIDACIJE U TKIVU PANKREASA KOD PACOVA}

Tehnološki razvoj, industrijalizacija i ekonomski razvoj doveli su do poboljšanja životnog standarda, ali $i$ emisije toksičnih metala $u$ životnoj $i$ radnoj sredini. Cilj ove studije je praćenje lipidne peroksidacije u uslovima akutne intoksikacije teškim metalom kadmijumom i protektivno dejstvo $\alpha$-liponske kiseline. U ovoj studiji korišćeni su zdravi albino laboratorijski pacovi ženskog pola, soja Wistar, starosti 2-3 meseca. Na osnovu dobijenih rezultata u ovoj studiji zapažamo da intoksikacija kadmijumom dovodi do povećanja nivoa malondialdehida (MDA) u homogenatu tkiva pankreasa. MDA je direktni pokazatelj lipidne peroksidacije. $\alpha$-liponska kiselina ukazuje na smanjenje i saniranje toksičnog efekta kadmijuma nakon njegove ekspozicije.

Ključne reči: Teški metali, kadmijum, $\alpha$-liponska kiselina, malondialdehid, lipidna peroksidacija 